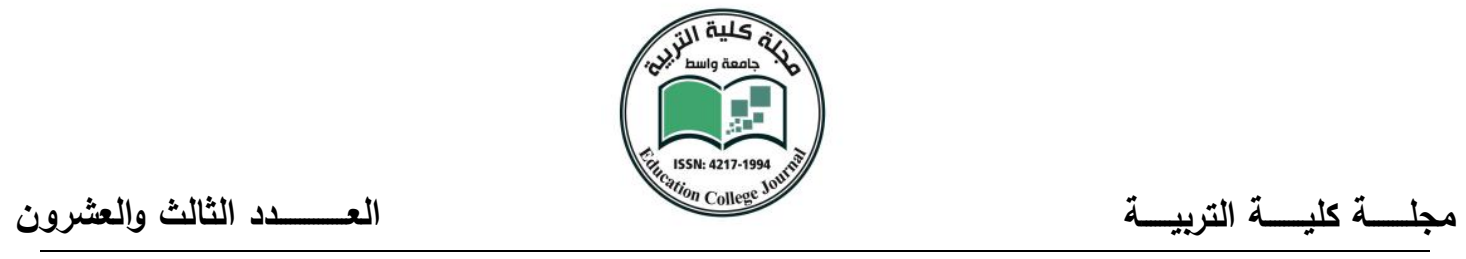

\title{
Variation in Official Translations: Investigating the English Translation of Government Offices and Positions in Iraq ${ }^{1}$
}

\author{
Lecturer: Mohammed Nasser Abdulsada \\ Department of English, Wasit University \\ mohmed.english@gmail.com
}

\begin{abstract}
$\underline{\text { Abstract }}$
Official Translation refers to the translation of official signboards which are found on government offices. In Iraq, signboards tagged on most government offices show considerable variation regarding translation; two or more offices tackling the same business show two different translations, as in College of Administration vs. College of Management, taking into account that these two institutions do the same business. The same applies to words such as Union, Federation and Association. Variant appear these words to be, yet they are used interchangeably to refer almost to the same sort of business. This phenomenon is noticeable on the signboards of most offices across Iraq. The present paper elaborates on the state of current translations, suggests alternative translations, reaches certain conclusions and finally proposes some recommendations that may help solve this problem.
\end{abstract}

Key Words: Translation, Lexical Variation, Government Titles and Positions, Iraq Offices. 


\section{مستخلص}

تشير الترجمة الرسمية إلى ترجمة التسميات الرسمية الموجودة على واجهات المؤسسات والمكاتب الحكومية للالالة على نوع العمل في هذه المؤسسات وفي العراق تظهر تسميات المؤسسات تباينا

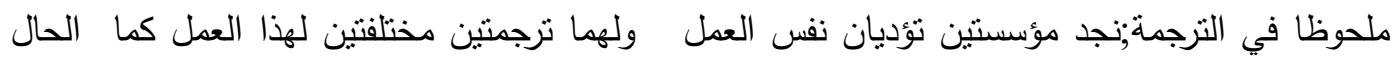

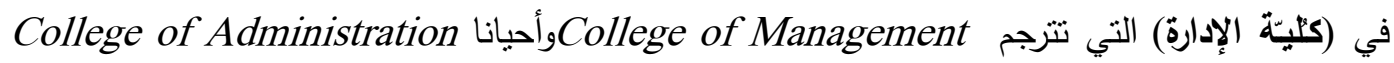
رغم أن كلاهما يقومان بنفس العمل وذات الثيء ينطبق على تنميات أخرى مثل (نقابة) فهي نتتوع في

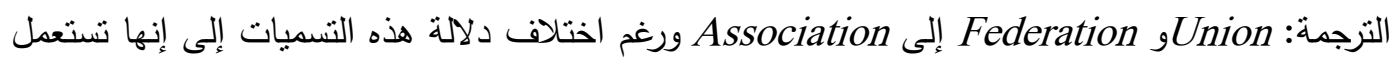
للإثارة إلى نفس المجال.تشيع تلك الظاهرة في ترجمة اغلب تسميات المؤسسات الرسمية في العراق بالرغم

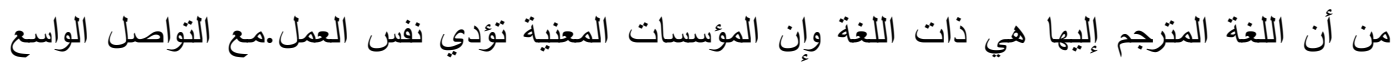

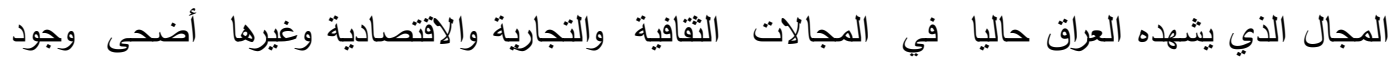

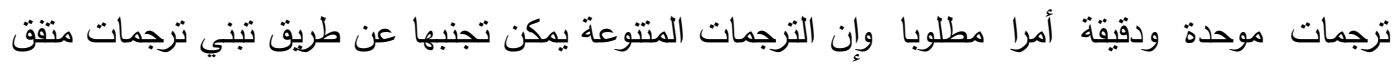

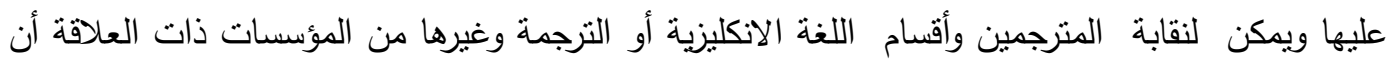

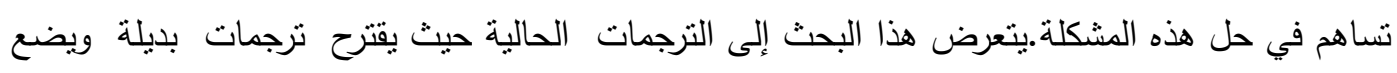
بعض الاستتاجات وفي النهاية يطرح بعض التوصيات التي يمكن أن نساعد في حل هذه الإثكالية. كلمات دالة:الترجمة،التتوع في الترجمة،تسميات المؤسسات والمناصب الحكومية،المؤسسات الرسمية في العراق 


\section{Subject Definition and Overview}

Variation in translation means that two or more translations are given for a single piece of speech, discourse or language (Baker,1992:88; Levý,2011:33; \& Urgese, 1984:39). In other words, that piece of discourse, whether it is a word, phrase, or sentence, is translated into different translations or phraseologies, given that the target language (TL) is the same for all these translations.

The reasons behind such variation has long been debated by linguists and specialists, and therefore this problem has been the concern of translators and linguists alike. The account for variation varies among linguists and specialists; some argue that the more synonymies a language has, the more varied translations will be. Others argue that the innovation on the part of some translators is likely to create new and different translations in the discourse related. Hansen (2003:77) and Bhatia (1993:172) point out that one of the reasons of variation in translation is the interlingual and intralingual differentiation. i.e., the existence of vocabulary items and words which co-refer to similar objects.

\section{Background and Review of Related Studies}

Variation in translation has been reported in the literature and previous studies, especially those related to English. Urgese (1984:49) reported a lot of variation in the French translations of popular and transactional texts having investigated selected texts written in English and French. Bell (1991:91) states that an utterance can be said or written in any language and recognized as a realization of a sentence of that particular language but the propositional meaning underpinning the utterance is universal rather than language-specific. He (ibid.)adds that stylistic conditions, such as discourse, medium, message, sender-receiver relationship, and context do affect the communication of a given code from the sender to the receiver.

Bhatia (1993:70) surveyed the English translations of certain texts of literature written in Bengali and Hindi and inferred that variation is inevitable and that it is sometimes language-specific. Hansen (2003:67) has revised the translation from Swedish into Danish and Norwegian, and concluded that no two translations are the same, because of multiplicity of the vocabulary related, 
misconceptions on translations and intercultural diversity. Freddi (2006:12) has made a research on the English subtitling or translation of Italian-speaking movies, whereby he reported a lot of variations in the area studied.

Mattsson (2006:7) investigated linguistic variation in the subtitling of swearwords in commercial television in Sweden. She concluded that the factors affecting the subtitling process in Sweden decide how features such as swearwords and discourse markers are treated in this mode of translation. She found that that both of these linguistic features are omitted to a large extent in all three target texts, and that the types/categories of features used are significantly influenced by the traditional way of using these words in Swedish written works and translations.

Hansen et al. (2007:55) have conducted a study on the German-English and English-German translations on a corpus of academic and periodical texts. They (ibid.) concluded that variation does exist when translating from German into English or vice versa in the texts mentioned. Hansen et al. (2007:90) focused on the Arabic-English translations in textbooks and manuals of language learning, and they (ibid.) maintained that synonymies, lexis and even the cultural content play a considerable role in the creation of variation.

Baumgarten and Özçetin (2008:293) studied the translation of business texts from German into English as they stated that German translations are influenced by their English source texts. They inferred that German translations differed from the German original texts, such that the German genre of business communication encompasses texts which linguistically resemble the English sister genre. They concluded that such variation shows the extent to which the English language influences German business communication. Sharkas (2009:23) investigated the translation of biological and medical terms from English into Standard Arabic in a few scientific texts, and she suggested that lack of proper vocabulary on the part of either language causes various translations.

Kerremans (2009:23) studied terminological variation in the bilingual dictionaries and glossaries written in English, French and Dutch. He found that certain patterns or tendencies can be derived from a comparative analysis of terminological variation in source texts and their translations. He also found that specialized translations contain at least as many terminological variants for a 
given unit of understanding as in the source texts or even more. Rosa (2012) studied linguistic variation as a problem posed by linguistic factors, and in particular by the relation between discourse and place. She suggested several major strategies for the translation of such literary pseudo varieties.

\section{Investigation of Current Translations}

Most official translations are characterized by a remarkable and considerable variation with respect to the vocabulary items used. These translations are such varied due to a set of factors that affect the phrasing of that translation.Recently, it has been found out that the titles of government offices in Iraq show a noticeable variation with respect to form or lexis. One can see that two offices engaged in the same business have their titles translated differently.Of these examples are College of Administration vs.College of Management, even though both colleges specialize in the same major. Also, Faculty is translated of Languages vs. College of Arts, where كليةdifferently(Sharkas,2009:12).

The word كيّة knlliye is translated as College and sometimes as Faculty. ${ }^{2}$ College is very broad, especially in European and American academics as it means a university that involves schools and institutes. On the other hand, Faculty refers mainly to the teaching body in a given school or university.

The two former terms are commonly used in the registers related, hence: Faculty of languages; College of Education. Faculty is almost used with humanities; Faculty of Arts, Faculty of Languages, Faculty of Law..etc., whereas College is used with humanities, science and other disciplines e.g. College of Science, College of Education, and College of Economics(Sanders et al.,2007:8).

\section{Possible Factors}

There is a set of factors that are thought to have been the possible motivator of variation. Of these is mental representation of words. Such representation plays a significant role in the creation of variation. It depends basically on the lexical formation of mental conceptions or formulations of the perceived entities. As early as 1978, Beaugrande (1978:25) argued that "The basis of the act of translation is not the original text, but rather the representation of the text that is eventually generated in the translator's mind." He (ibid.) goes on to explain that 
"the mental representation of the text that is finally registered in the translator's mind is not identical with the original text" because the translator's reading "may well have led to a redistribution of prominence within the text".

Johnson-Laird (1987:189) maintained that "the recognition of words is seldom an end in itself, because listeners want to understand what they hear. Lexical meanings are the ingredients from which the sense of an utterance is made up, and its syntactic structure is the recipe by which they are combined."

Wu (2002:534) states that " There seems to be an uncontroversial observation that a translator is both free and constrained in a translating task. " Following Beaugrande's discussion (1978), one may quite argue that a translator is free in generating a mental representation of the SL and that $\mathrm{s} / \mathrm{he}$ is constrained in presenting in the target language what has been generated in his/her mental representation. Fig. (1) below shows the formation of mental representation in translation.

Fig. (1) Mental Formation of Variant Translations

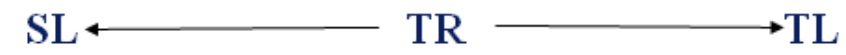

ARABIC

ENGLISH

LITERAL/ WORD FOR WORD

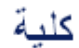

/kullijə/

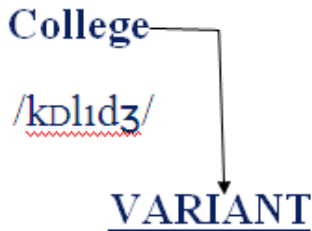

Faculty

School 


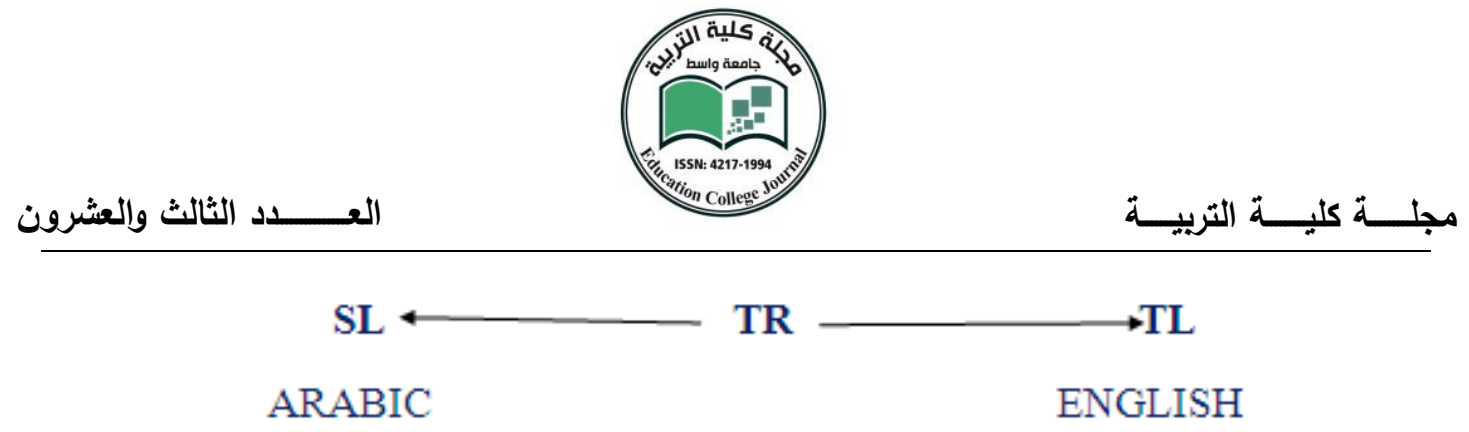

\section{LITERAL/WORD FOR WORD}

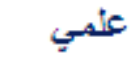

$/ \varsigma_{1} 1 \mathrm{mi} 1 /$
Scientific

/saintifik/
VARIANT

Academic

$\mathrm{SL}=$ Source

$\mathrm{T}=$ Target Language

$\mathrm{T}=$ Translation
Scholarly

Fig. (1) above shows the mental formation of the translation of (كلية) Kulliye, where the face value form of this word is the counterpart in the TL, which explains the use of College rather than the other variants. In other words, when translating, the mental conception is the first form the translator produces in the TL. The same applies to other cases in which the lexical form in the TL plays a significant role in the production of variation-where other translators will resort to Faculty or School when they translate the same word to English.

9ilmiye is used loosely in translation. It is used in such as Scientific Conference, Scientific Journal, Scientific Library, Scientific Affairs and the like. Scientific proper denotes pure and applied sciences and the translations above are not accurate because they hold the meaning at a face value, just because the counterpart of this word in Arabic is the same(Biber,1999:133).This can be avoided by using words such as Academic or Scholarly because conferences, magazines or university sections or departments are not involved in science-based activities only. Conferences, libraries and journals are not science- 
dedicated, they involve many disciplines and areas unless otherwise they are dedicated to a specific field as in Humanities Journal, where the journal in this sense is limited to Humanities, as the opposite to Sciences.

(إدارة) Idare is translated either as management or administration. This is due to the misconception held about this word in English. Non-native speakers find that both words mean the same as they are not different in reference. It is this which creates variable translations, such as College of Management and College of Administration.

The word (دائرة) Da? ire has several translations being used in government businesses; it is translated as Office, Department and Directorate. The reason behind this might be the fact that these words are apparently mistaken for synonymous words, even though they are not as such. When that word is translated into these three words, the functional meaning of that word will be retained. Thus these translations can be used interchangeably.

معاون العميدMu9awin 9emeed is Assistant Dean, which is wrong.Assistant suggests that there are two Deans and not one, as it is in Assistant Director in film-making where two directors co-direct a movie.

term but موظف MuweDDef is translated into Government Worker or Employee, worker does not necessarily refer to people working in state-run businesses only, as it also refers to those working in private or non-government businesses, this then makes it more restrictive than Employee. Therefore, Civil Servant would be more comprehensive in translation than the two previous terms and it is also the term used in the global offices related (Habash et al., 2007:125).

is translated as Virtual Science Library and is abbreviated as (VSL), which is not accurate and the required translation would be Virtual Academic Library (VAL) or Virtual Scholarly Library (VSL).

Translation of bilingual IDs, or the government IDs that appear in English and Arabic, carry a lot of pitfalls or errors in phraseology. For example, Names are ill-translated, 
Isim Ruba9ee is translated as Quadruple Name, which is wrong. It can be translated as Full Name or First, Second,(and) Third فصيلة الدمباعilence Fesilet Name(s).

Dem is translated as Blood Type and Blood Group, and the latter, but not the former, is the common term.

the term وظيفة WeDeefa is translated as Job, Position, Work Type and Occupation. The multiple translations can be avoided by adopting a single term and it is left to translators to choose the term that best fits the Arabic counterpart.

شؤون علمية Shu?uun 9ilmiye is translated as Scientific Affairs.It can be rendered Academic Affairs to achieve accuracy in translation. The computer proficiency known as IC3, is شهادة قيادة الحاسوبtest, $\quad$ while IC3 stands for Internet and translated as Computing Core Certification (Wikipedia, 2011:2). An appropriate the above abbreviation would be شهادة أساسيات الحاسوب و الانترنت. translation for the

\section{Study Findings}

The study has reached the following results:

1. Variation in translation may be attributed to the presence of synonyms and near-synonyms at the translator's disposition. These synonyms represent the only variants in translation.

2. There are other factors that lead to variation in translation from SL to TL, such as lexical counterparts, equivalence, and correspondence in meaning.

\section{Recommendations}

The following are some recommendations put forward to help solve the problem of variant translations:

1.Departments of English and/or Departments of Translation and the Iraqi Translators' Union can approve and set translations which are single, exact and unified. 
2.Departments of English and/ or Departments of Translation found in the local universities may establish some consulting offices the job of which is to issue certified translations to the local government offices when necessary.

3.Ministry of Higher Education and Scientific Research may play a considerable role in this respect being the highest academic authority in the country. The Ministry mentioned may establish an institution or a centre that specializes in delivering certified translations to all offices, private and public, that need its business titles to have translated into English.

4. Government offices may seek the aid of the said bodies in the translation of its titles.

\section{Conclusions}

In the light of the discussions stated above, the following conclusions have been reached:

1.Translation of government and official business titles and positions shows a noticeable variation in terms of lexicology.

2.Creativity on the part of translators, the existence of synonymies, the ill-use of certain vocabulary items, and the lack of reliable translations are the factors that likely trigger variation in such translations.

3. Government offices and businesses often seek translation from unreliable or non-certified sources, which therefore results in variable translations.

4.The absence of single and approved translations among the translators and the bodies related makes variation the norm rather than the exception.

\section{Further Areas of Research}

1.There are a few words in Arabic related to positions and that have so far no or single translation, particularly those نقيب such as نقيب ،قيب الصحفيين accurate and ققيب الأطباءheaded with .These titles need to be considered as to translation. نقيب المعلمين،المهندسين 
Further, titles of the administrative divisions need to accounted for in translation. example, محافظة For has two different translations; Governorate and Province, the word

which adds a further significance to this area of study.

2.The current paper has focused on the translation of governmental or official businesses and offices. However, a further study can tackle the English version of governmental and official transactions, the written ones, to show relevance and variation in the translation of these transactions.

3. A further study can be conducted on the role of synonyms in English-Arabic translations.

4. Variation may be attributed to the contrast of meaning between ostensiblity and opaqueness, which is another factor that need to be investigated in order to account for variation.

\section{NOTES:}

${ }^{1}$ I would like to thank Associate Professor Hala Sharkas of UAE University, UAE, for her helpful notes on the early version of this paper.

${ }^{2}$ Transliteration will be used here whenever an Arabic title or word is mentioned, to show the phonological and lexical significance of the words under study. 


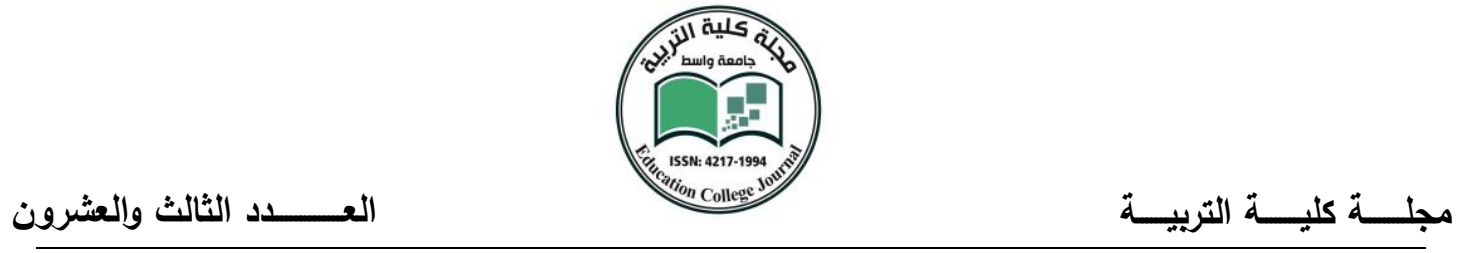

\section{References}

- Baker, M. (1992). In Other Words: A Coursebook in Translation.New York: Routledge Publishers.

- Baumgarten, N. \& Özçetin, D. (2008).Linguistic Variation Through Language Contact in Translation. In Peter Siemund \& Noemi Kintana. (eds.). Language Contact and Contact Languages. Amsterdam/Philadelphia: John Benjamins Publishing Company, (pp. 293-316).

- Beaugrande, R. (1978). Factors in a Theory of Poetic Translating. Assen, The Netherlands: Van Gorcum.

- Bell, R.T.(1991). Translation and Translating: Theory and Practice. London \& New York: Longman Group Limited.

- Biber, D. (1999). Dimensions of Register Variation. Cambridge: Cambridge University Press.

- Bhatia, V. (1993). Analysing Genre: Language Use in Professional Settings. London: Longman.

- Freddi, G. (2006).Continuity and Variation Across Translations: Phraseology in the Pavia Corpus of Film Dialogue. Rome, University of Pavia Master Thesis.

- Habash,N., Soudi, A.\& Buckwalter, T.(2007).On Arabic Transliteration. In Abdelhadi Soudi, Antal van den Bosch \& Günter Neumann.(eds.). (2007). Arabic Computational Morphology:Knowledge-based \& Empirical Methods. Text, Speech \& Language Technology. Vol.38. Stuttgart: Springer Verlag.

- Hansen, S. (2003). The Nature of Translated Text: An Interdisciplinary Methodology for Investigation of Specific Properties of Translations. Saarbrücken Dissertations in Computational Linguistics \& Language Technology. Saarbrücken: Universität des Saarlandes.

- Hansen, S.,Neumann, S.,\& Steiner, E.(2007). "Cohesive Explicitness in an EnglishGerman Translation Corpus" Languages in Contrast, 7:2(241-265).

- Johnson-Laird, P.N. (1987)."The Mental Representation of the Meaning of Words" Cognition, 25 (189-211). 
 \\ - Kerremans, K.(2009). A Comparative Study of Terminological Variation in Specialised Translation. 17 $7^{\text {th }}$ European LSP Symposium, Aarhus, Denmark, August 17-21, 2009. \\ - Levý, J. (2011). The Art of Translation. Amsterdam: John Benjamins Publishing Company. \\ - Mattsson, J.(2006).Linguistic Variation in Subtitling: The Subtitling of Swearwords and Commercial Television. MuTra 2006-Audiovisual Translation Conference, Copenhagen, May 1-5, 2006, (pp.1-10).}

- Rosa, A.A. (2012). Translating Place: Linguistic Variation in Translation. Word and Text: A Journal of Literary Studies and Linguistics, 2:1(75-97).

- Sanders, G., Parvaz, A., Rubenstein,C., Doran, J. and Oshika, Y.(2007).Normalization for Automated Metrics.File retrieved at http://www.nist.md.edu.us translation/metrics benglish/arabic/info.html.pdf. (Accessed 2/6/2010).

- Sharkas, H.(2009).Translation Quality Assessment of Popular Science Articles. Transkom Zeitschrift für Translation und Kommunikation. http://www. trans-kom.eutrans. (Accessed 20/7/2014).

- Urgese,T.(1984)."Translation: How, When and Why" English Teaching Forum, 27:1, (38-45).

- Wikipedia/variation in translation. (2011). Wikipedia is available at http://www. wikipedia.com (Accessed 2/7/2011).

- $\quad W u, Q$. (2002). "Interaction Between Language and the Mind Through Translation: A Perspective from Profile/Base Organization" Meta:journal des traducteurs/ Translators' Journal, 47:4 (532-563). 
APPENDIX: Some Proposed Translations Compared with the Current Translations. Index (1)

\begin{tabular}{|c|c|c|c|c|}
\hline ż & Title & Current Translation & $\begin{array}{c}\text { Proposed } \\
\text { Translation }\end{array}$ & Remarks \\
\hline- & معاون العميد & Assistant dean & Vice-Dean & $\begin{array}{l}\text { The position is for one person only } \\
\text { and assistant-dean implies that } \\
\text { there are two deans, as, for } \\
\text { example, in assistant-director in } \\
\text { film-making, where more than one } \\
\text { director co-direct a film. Sub-Dean } \\
\text { serves the same purpose and it is } \\
\text { also used, but it is not as common } \\
\text { as Vice-Dean. }\end{array}$ \\
\hline $\mathrm{N}$ & رئيس الجامعة & President & Chancellor & $\begin{array}{l}\text { Chancellor is used to refer to that } \\
\text { position in many universities } \\
\text { around the world }\end{array}$ \\
\hline$m$ & مساعد رئيس & Assistant President & $\begin{array}{c}\text { Vice- } \\
\text { Chancellor }\end{array}$ & See Note No. 1 above \\
\hline$\nabla$ & الثؤون العلمية & Scientific Affairs & $\begin{array}{l}\text { Academic } \\
\text { Affairs } \\
\text { or } \\
\text { Academics } \\
\text { only }\end{array}$ & $\begin{array}{l}\text { Whether in colleges of } \\
\text { education/arts and/or similar } \\
\text { disciplines, or these of science, this } \\
\text { position is concerned with how } \\
\text { departments work, examinations, } \\
\text { students' activities. etc; it is not } \\
\text { restricted to science(s) proper. }\end{array}$ \\
\hline in & الافتبنة العية & $\begin{array}{c}\text { VSL; Virtual Science } \\
\text { Library }\end{array}$ & $\begin{array}{l}\text { Virtual } \\
\text { Academic } \\
\text { Library/ } \\
\text { Virtual } \\
\text { Scholarly } \\
\text { Library/ } \\
\text { Virtual } \\
\text { Library }\end{array}$ & $\begin{array}{l}\text { Libraries, in general, involve many } \\
\text { fields, disciplines and majors and } \\
\text { they are not restricted to sciences } \\
\text { only. }\end{array}$ \\
\hline 0 & علاقات عامة & $\begin{array}{l}\text { Public Affairs/ Public } \\
\text { Relations }\end{array}$ & $\begin{array}{l}\text { Public } \\
\text { Affairs }\end{array}$ & $\begin{array}{l}\text { Affairs is more common than } \\
\text { relations }\end{array}$ \\
\hline
\end{tabular}




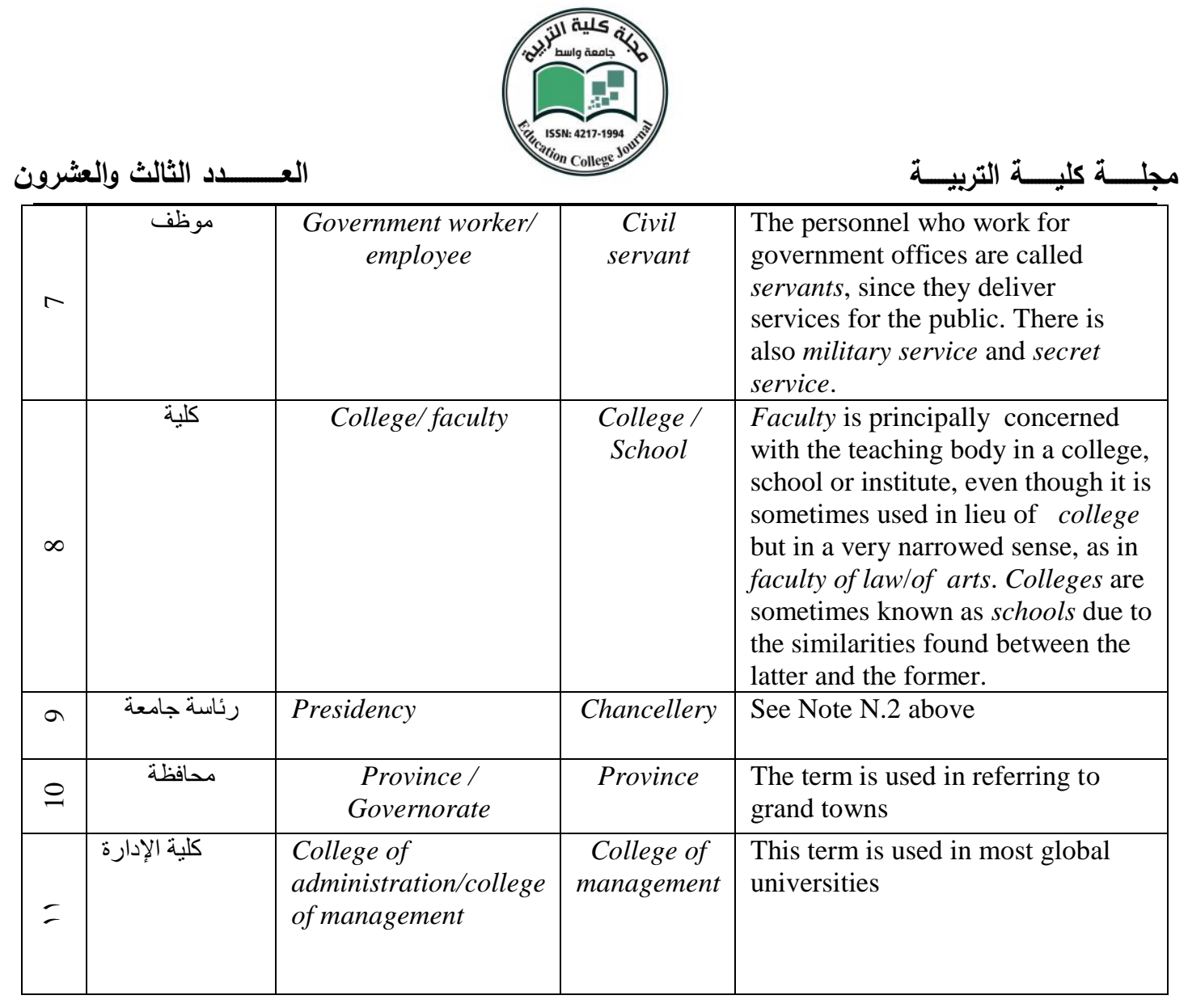




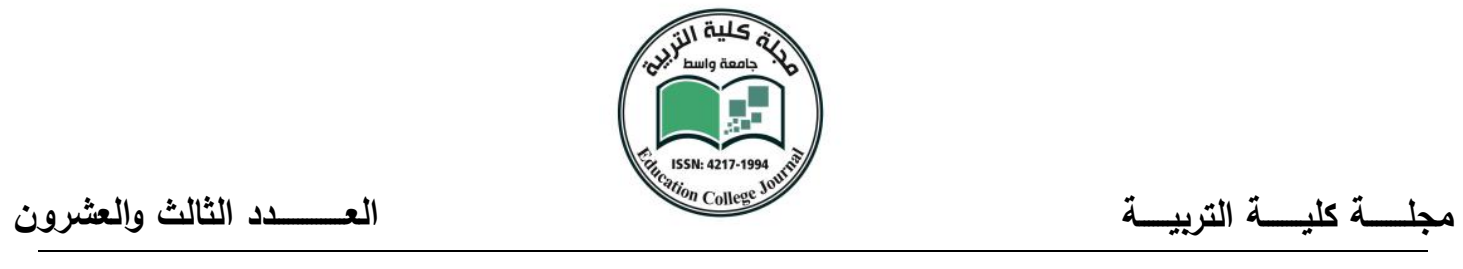

Index (2)

\begin{tabular}{|c|c|c|c|c|}
\hline $\mathbf{Z}$ & Title & $\begin{array}{c}\text { Current } \\
\text { Translation }\end{array}$ & $\begin{array}{c}\text { Proposed } \\
\text { Translation }\end{array}$ & Remarks \\
\hline$\cong$ & مؤتمر علمي & $\begin{array}{c}\text { Scientific } \\
\text { Conference }\end{array}$ & $\begin{array}{l}\text { Academic } \\
\text { conferencel } \\
\text { Academic } \\
\text { Convention / } \\
\text { Conference or } \\
\text { Convention only }\end{array}$ & $\begin{array}{l}\text { This is justified by the fact that a } \\
\text { conference in a multi-disciplinary } \\
\text { college or university, unless } \\
\text { otherwise it is a college/institute } \\
\text { of science, may cover a wide } \\
\text { range of majors; humanities, } \\
\text { economics and other social } \\
\text { sciences, and it is not necessarily } \\
\text { restricted to scientific majors. }\end{array}$ \\
\hline$\cong$ & المكتبة الالكترونية & $\begin{array}{l}\text { Electronic } \\
\text { library }\end{array}$ & E-Library & $\begin{array}{l}\text { The prefix E- has become the } \\
\text { fashion in referring to network- } \\
\text { based exchanges and businesses, } \\
\text { hence } e \text {-mail, e-signature, } e \text { - } \\
\text { commerce, ..etc }\end{array}$ \\
\hline \pm & مدير عام & $\begin{array}{l}\text { General } \\
\text { Director/ } \\
\text { General } \\
\text { Manager }\end{array}$ & $\begin{array}{l}\text { Director general } \\
\text { Manager General }\end{array}$ & $\begin{array}{l}\text { Postposed adjectives are used in } \\
\text { the designation of many titles, } \\
\text { positions and chairs. e.g. post } \\
\text { master general and brigadier } \\
\text { general. }\end{array}$ \\
\hline$n$ & دائرة & $\begin{array}{c}\text { Officel } \\
\text { Department / } \\
\text { Directorate }\end{array}$ & Office only & $\begin{array}{l}\text { Government-run departments and } \\
\text { divisions are often referred to as } \\
\text { offices, as this term covers many } \\
\text { businesses }\end{array}$ \\
\hline 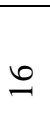 & الاسم الرباعي & $\begin{array}{l}\text { Quadruple } \\
\text { name }\end{array}$ & $\begin{array}{l}\text { Full-name/ first- } \\
\text { second-middle-last } \\
\text { name }(s)\end{array}$ & $\begin{array}{l}\text { Quadruple indicates a form or } \\
\text { appearance rather than content }\end{array}$ \\
\hline & الكلية التقنية & $\begin{array}{l}\text { Technical } \\
\text { College }\end{array}$ & Polytechnic & $\begin{array}{l}\text { Polytechnic is a college, school or } \\
\text { institute with different,often } \\
\text { applied,departments. This word is } \\
\text { a noun and not adjective, and thus } \\
\text { it needs not to be postmodified by } \\
\text { College or Institute. }\end{array}$ \\
\hline$\leq$ & و الاتحاب في العام للأدباء & $\begin{array}{l}\text { The Union of } \\
\text { Iraqi Writers }\end{array}$ & $\begin{array}{l}\text { The Iraqi General } \\
\text { Union of Writers } \\
\text { and Litterateurs }\end{array}$ & $\begin{array}{l}\text { The current translation gives no } \\
\text { clue to two parts mentioned in SL: } \\
\text { الأدباء and }\end{array}$ \\
\hline
\end{tabular}




\begin{tabular}{l} 
مسر بغداد الكبير \\
\hline 2
\end{tabular}


ألتباين في الترجمة الرسمية:تقصي الترجمة الانجليزية لعناوين بعض المؤسسات والمناصب الحكومية في العراق

تشير الترجمة الرسمية إلى ترجمة التسميات الرسمية الموجودة على و اجهات المؤسسات و المكاتب

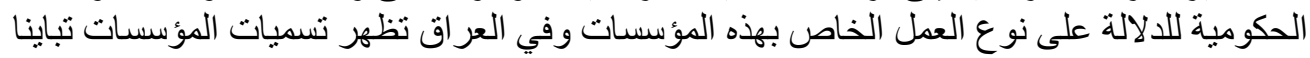
ملحوظا في الترجمة. في هذا السياق نجد مؤسستين تؤديان نفس العمل تقدمان ترجمتين مختلفتين لهذا

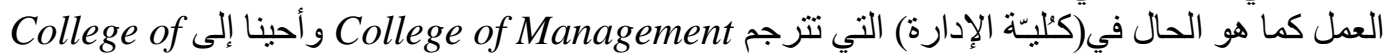
Administration

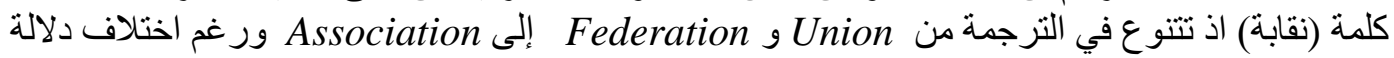

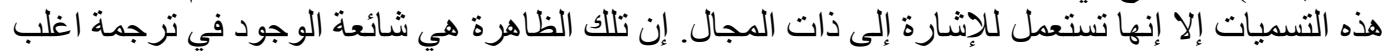

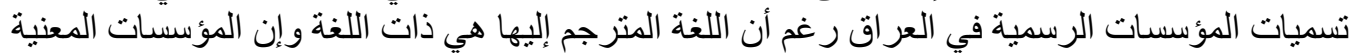

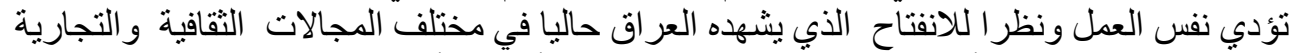

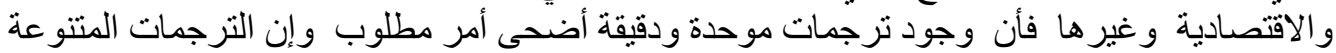

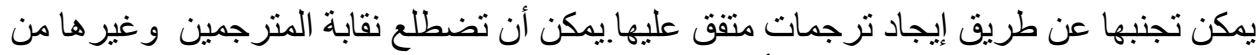

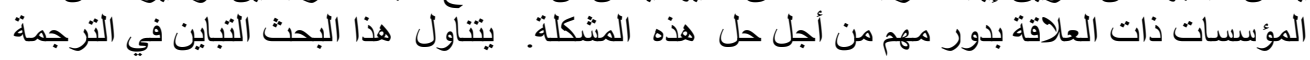

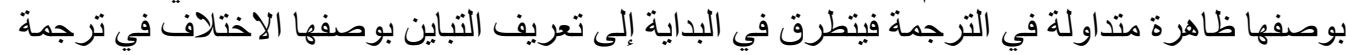

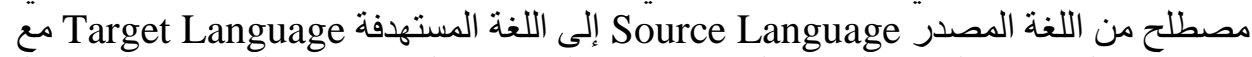

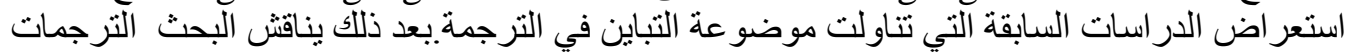

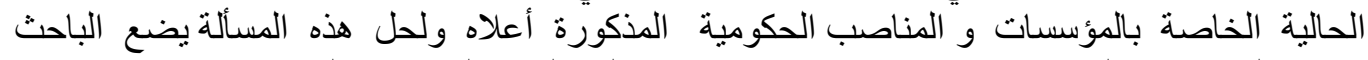

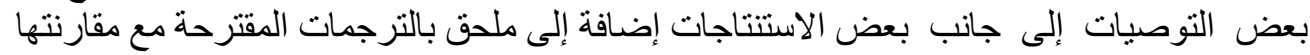
بالترجمات الحالية.

أهم النتائج التي توصل إليها البحث:

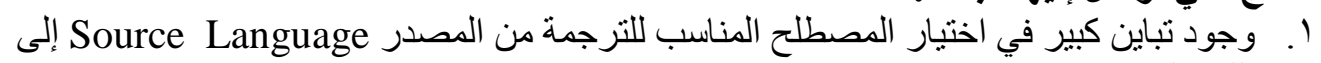

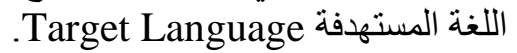

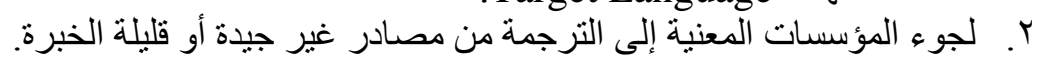

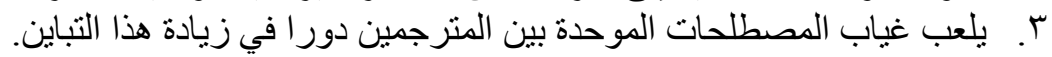

التوصيات المقترحة:

ا ـ ضرورة قيام نقابة المترجمين بتوحيد المصطلحات من أجل اعتمادها في الترجمة.

؟. . يمكن أن تلعب أقسام اللغة الانجليزية أو الترجمة الموجودة في الجامعات دور مهم في رفد حاجة

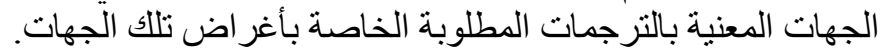

